\title{
THE ELECTROPHORETIC PATTERNS OF PROTEINS IN SYNOVIAL FLUID AND SERUM IN RHEUMATOID ARTHRITIS ${ }^{1,2}$
}

\author{
By G. E. PERLMANN,3 M. W. ROPES, D. KAUFMAN, AND W. BAUER \\ (From the Departments of Medicine of the Massachusetts General Hospital and Harvard \\ Medical School, Boston, Mass.)
}

(Submitted for publication August 4, 1953 ; accepted September 23, 1953)

The electrophoretic patterns of plasma obtained from patients with rheumatoid arthritis have been described by many investigators and are discussed in the preceding paper (1). The electrophoretic distribution of proteins in synovial fluid has been studied less extensively (2-5). It seemed of interest, therefore, to determine the various patterns which may occur in joint fluid of patients with rheumatoid arthritis and to determine whether a correlation exists with the duration and severity of the disease and with other characteristics of joint fluid which have been shown to reflect the degree of inflammation of the synovial tissue (6).

\section{EXPERIMENTAL TECHNIQUES}

A description of the technique employed in the aspiration of the synovial fluid from the knee as well as the methods used for the cell counts and for the characterization of mucin are adequately described in a recent publication (6). The procedures adopted for the electrophoretic and chemical analyses are identical with those given in the preceding paper of this series (1), with the exception that the synovial fluid was collected without an anticoagulant and is therefore compared with the corresponding serum.

\section{RESULTS}

Since normal human synovial fluid cannot be obtained in quantities sufficient for electrophoretic analysis, fluids from non-hemorrhagic effusions in traumatic arthritis ${ }^{4}$ were taken as a basis of comparison. ${ }^{5}$ As shown with the aid of the electropho-

1 This is publication No. 154 of the Robert W. Lovett Memorial for the Study of Crippling Disease, Harvard Medical School.

2 The expenses of the investigation were defrayed in large part by a grant from the Commonwealth Fund.

${ }^{8}$ Now at the Rockefeller Institute, New York.

4 We are indebted to Dr. James Heyl of Exeter, New Hampshire, for furnishing this material.

- Traumatic fluids have been found to show less change from normal in cells, sugar and protein content and state of mucin than fluid from any other type of joint disease (6). retic patterns of Figure 1a, traumatic fluids have five distinct fractions characterized by mobilities similar to those of the albumin, $\alpha_{1^{-}}, \alpha_{2^{-}}, \beta-$ and $\gamma$-globulin of serum (cf. references 3 and 4 ). In addition, there is always present a component, denoted here as "Hy," which migrates with a velocity exceeding that of the albumin. Electrophoretic separation, followed by chemical analysis, ${ }^{\circ}$ revealed that this substance is the polysaccharide, hyaluronic acid, which occurs in synovial fluid, and which has been studied electrophoretically also by Hesselvik (8) and Blix (9).

As illustrated in Table I, which records the electrophoretic composition of six traumatic synovial fluids, the apparent relative concentration of albumin is always higher in the fluid than in the corresponding serum, whereas that of the $\alpha_{2}$-globulin is lower. A similar relationship of distribution of electrophoretic components to that of serum has been found previously in this laboratory in the analyses of joint fluid and lymph of cattle $(7,10)$.

In Table I are also given the electrophoretic mobilities of the different components which reveal a close agreement between the serum and the synovial fluid proteins. The value of $-8.9 \times 10^{-5}$ $\mathrm{cm} .^{2} \mathrm{sec}^{-1}$ volt ${ }^{-1}$ recorded by us for hyaluronic acid is, however, lower than that reported by other workers $(8,9,11)$. If in electrophoretic analysis a phosphate buffer of $\mathrm{pH} 7.7$ and 0.2 ionic strength is substituted for the sodium diethylbarbiturate, the mobility of hyaluronic acid is about one unit more negative. A similar observation, i.e., that a given solvent influences the migration of a polysaccharide or a mucoprotein to a greater extent than that of most proteins, has been made recently by Perlmann, Tamm, and Horsfall (12). This may

- Electrophoretic separation and chemical analysis carried out on one sample of cattle fluid and one fluid from a patient with rheumatoid arthritis (7). 

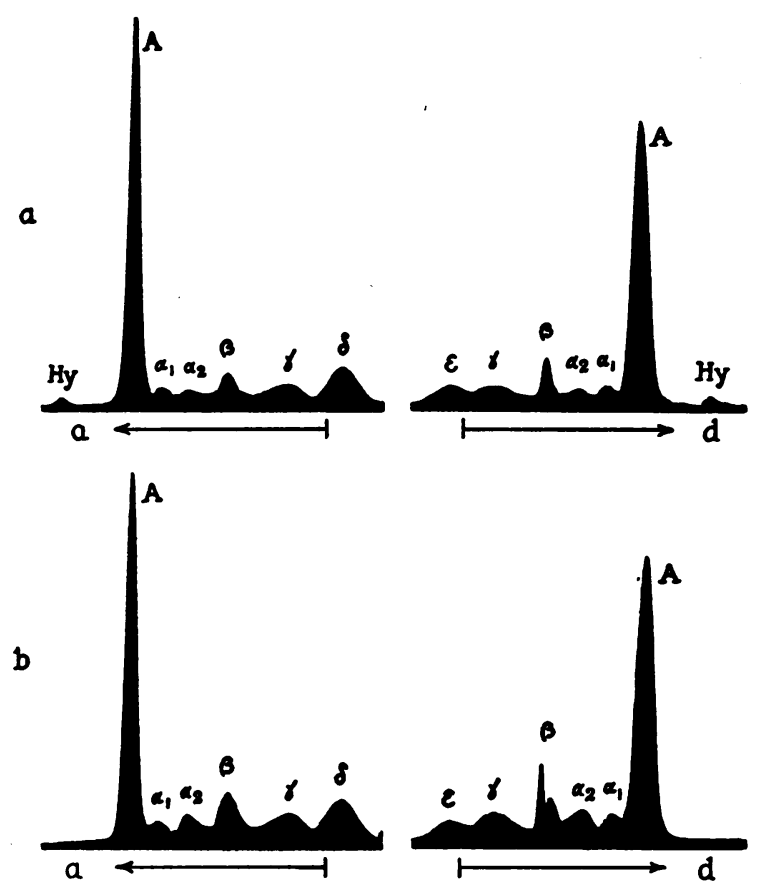

Figs. la and 1b. Electrophoretic Patterns of a 1.8 Per Cent Solution of Proteins of a Traumatic Synovial Fluid (a) and of the Corresponding Serum (b)

Electrophoresis was carried out in sodium diethylbarbiturate buffer of $\mathrm{pH} 8.6$ and $\Gamma / 20.1$ for 12,600 seconds at a potential gradient of 5.3 volts per centimeter.

explain, in part at least, the lower values recorded for hyaluronic acid in the present study.

Measurements were carried out on synovial fluids and sera of 21 patients with rheumatoid arthritis. Four of the patients had the disease for less than one year, two from one to two years, five from two to five years, and six from five to ten years and four over ten years. Classification as to stage of disease and functional ability was made by the criteria approved by the American Rheumatism Association (13). ${ }^{7}$ In all, 31 fluids and

\footnotetext{
7 The stage of disease is determined by the degree of presumably irreversible involvement rather than activity. Stage I is characterized only by subchondral bone atrophy; Stage II by cartilaginous and cortical destruction; Stage III by deformities such as ulnar deviation and subluxation; Stage IV by fibrous or bony ankylosis. Nodules and significant muscle atrophy must not be present in Stage I. The functional classes are: I. Ability to carry on all usual duties without handicaps; II. Adequate for normal activities despite handicap of discomfort or limited motion in one or more joints ; III. Limited only to few or none of the duties of usual occupation or self-care; IV. Incapacitated, largely or wholly; little or no self-care.
}

28 sera were studied. On the basis of the results of the electrophoretic analyses, the synovial fluids can be arranged in three distinct groups. As shown by representative cases listed in Table II, Group A contains fluids in which the apparent relative concentration of albumin is higher than in the corresponding serum, despite a wide range in concentration of albumin in the serum. In Group B are included those cases which have essentially the same relative distribution of electrophoretic components as the serum (see Figure 2); whereas, as illustrated with the aid of Figure 3, the fluids of Group $\mathrm{C}$ are characterized by a predominantly high concentration of $\gamma$-globulin. Two of the three cases studied by Svartz and Olhagen (3) apparently fall into Group $A$ and the other into Group B.

Correlation between the electrophoretic pattern of joint fluids and the severity of disease is not good. Mild cases tend to show the type of pattern of Group A, with albumin concentrations higher in the fluid than in the serum. Of the ten cases in this category, four were in Stage I, three in Stage II, and three in Stage III. Of the cases in Group B, on the other hand, one was in Stage I, four in Stage II, two in Stage III, and one in Stage IV. However, despite this possible clinical correlation, no apparent connection exists between
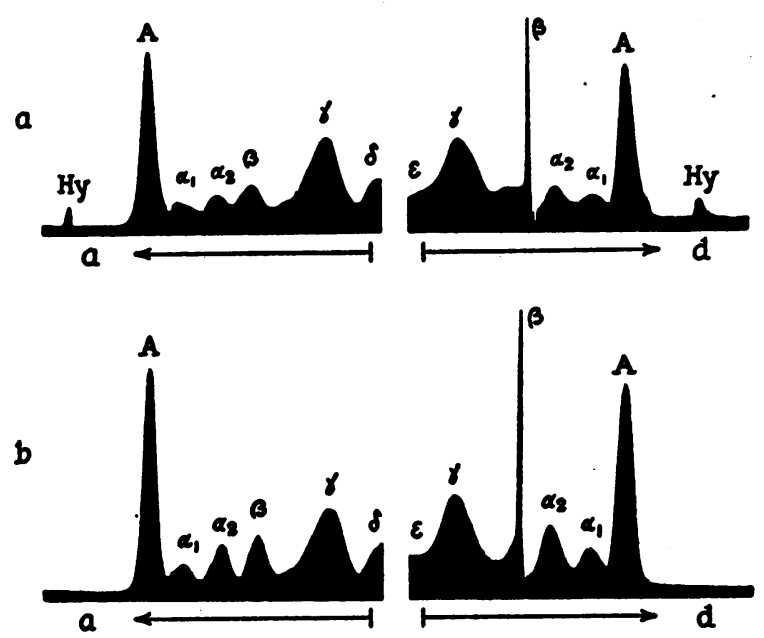

Figs. 2a ANd 2b. Electrophoretic Patterns of a 1.8 Per Cent Solution of Proteins of the Synovial Fluid (a) and the Serum (b) of a Patient with Rheumatoid Arthritis, Representative of Group $B$

Electrophoresis was carried out in sodium diethylbarbiturate buffer of $\mathrm{pH} 8.6$ and $\mathrm{\Gamma} / 20.1$ for 14,400 seconds at a potential gradient of 5.1 volts per centimeter. 
TABLE I

Electrophoretic distribution of proteins in serum and synovial fluid from traumatic arthritis *

\begin{tabular}{|c|c|c|c|c|c|c|c|c|c|c|c|c|c|}
\hline \multirow[b]{3}{*}{ Case } & & \multirow{3}{*}{$\begin{array}{c}\text { Total } \\
\text { protein } \\
\mathrm{Gm} . / 100 \mathrm{cc} .\end{array}$} & \multicolumn{5}{|c|}{ Concentrations in per cent as } & \multicolumn{6}{|c|}{ Mobilities $\times 10^{-5} \mathrm{~cm}^{2}$ volt. $^{-1} \mathrm{sec} .^{-1}$} \\
\hline & & & \multirow[b]{2}{*}{ Albumin } & \multicolumn{4}{|c|}{ Globulins } & \multirow[b]{2}{*}{ "Hy" } & \multirow[b]{2}{*}{ Albumin } & \multicolumn{4}{|c|}{ Globulins } \\
\hline & & & & $\alpha_{1}$ & $\alpha_{2}$ & $\beta$ & $\boldsymbol{\gamma}$ & & & $\alpha_{1}$ & $\alpha_{2}$ & $\beta$ & $\gamma$ \\
\hline A. B. & $\begin{array}{l}\text { Fluid } \\
\text { Serum }\end{array}$ & $\begin{array}{l}2.99 \\
6.75\end{array}$ & $\begin{array}{l}61.5 \\
53.8\end{array}$ & $\begin{array}{l}5.5 \\
5.8\end{array}$ & $\begin{array}{l}5.5 \\
9.8\end{array}$ & $\begin{array}{l}12.9 \\
13.4\end{array}$ & $\begin{array}{l}14.6 \\
17.2\end{array}$ & -9.0 & $\begin{array}{l}-6.6 \\
-6.5\end{array}$ & $\begin{array}{l}-5.3 \\
-5.3\end{array}$ & $\begin{array}{l}-4.4 \\
-4.0\end{array}$ & $\begin{array}{l}-3.3 \\
-3.1\end{array}$ & $\begin{array}{l}-1.3 \\
-1.2\end{array}$ \\
\hline M. C. & $\begin{array}{l}\text { Fluid } \\
\text { Serum }\end{array}$ & $\begin{array}{l}3.57 \\
7.12\end{array}$ & $\begin{array}{l}64.2 \\
57.6\end{array}$ & $\begin{array}{l}3.3 \\
3.5\end{array}$ & $\begin{array}{l}7.4 \\
9.9\end{array}$ & $\begin{array}{l}11.1 \\
13.2\end{array}$ & $\begin{array}{l}14.0 \\
15.8\end{array}$ & -8.9 & $\begin{array}{l}-6.2 \\
-6.2\end{array}$ & $\begin{array}{l}-5.1 \\
-5.1\end{array}$ & $\begin{array}{l}-4.1 \\
-4.1\end{array}$ & $\begin{array}{l}-2.9 \\
-2.8\end{array}$ & $\begin{array}{l}-1.2 \\
-1.2\end{array}$ \\
\hline J. C. & $\begin{array}{l}\text { Fluid } \\
\text { Serum }\end{array}$ & $\begin{array}{l}3.54 \\
6.50\end{array}$ & $\begin{array}{l}64.6 \\
55.6\end{array}$ & $\begin{array}{l}4.5 \\
5.3\end{array}$ & $\begin{array}{l}5.8 \\
8.9\end{array}$ & $\begin{array}{l}12.3 \\
15.2\end{array}$ & $\begin{array}{l}12.8 \\
15.0\end{array}$ & -8.9 & $\begin{array}{l}-6.4 \\
-6.4\end{array}$ & $\begin{array}{l}-5.3 \\
-5.3\end{array}$ & $\begin{array}{l}-4.4 \\
-4.2\end{array}$ & $\begin{array}{l}-3.2 \\
-3.2\end{array}$ & $\begin{array}{l}-1.5 \\
-1.4\end{array}$ \\
\hline P. M. & $\begin{array}{l}\text { Fluid } \\
\text { Serum }\end{array}$ & $\begin{array}{l}3.45 \\
6.94\end{array}$ & $\begin{array}{l}70.3 \\
58.5\end{array}$ & $\begin{array}{l}4.1 \\
4.3\end{array}$ & $\begin{array}{l}5.1 \\
8.6\end{array}$ & $\begin{array}{r}8.9 \\
15.5\end{array}$ & $\begin{array}{l}11.6 \\
13.1\end{array}$ & -8.9 & $\begin{array}{l}-6.3 \\
-6.5\end{array}$ & $\begin{array}{l}-5.2 \\
-5.5\end{array}$ & $\begin{array}{l}-4.1 \\
-4.3\end{array}$ & $\begin{array}{l}-3.0 \\
-3.0\end{array}$ & $\begin{array}{l}-1.2 \\
-1.3\end{array}$ \\
\hline L. 0 . & $\begin{array}{l}\text { Fluid } \\
\text { Serum }\end{array}$ & $\begin{array}{l}3.90 \\
6.50\end{array}$ & $\begin{array}{l}65.2 \\
57.9\end{array}$ & $\begin{array}{l}4.1 \\
4.6\end{array}$ & $\begin{array}{r}7.7 \\
10.7\end{array}$ & $\begin{array}{l}12.5 \\
15.1\end{array}$ & $\begin{array}{l}10.5 \\
11.7\end{array}$ & -8.5 & $\begin{array}{l}-6.0 \\
-6.3\end{array}$ & $\begin{array}{l}-5.0 \\
-5.3\end{array}$ & $\begin{array}{l}-4.0 \\
-4.2\end{array}$ & $\begin{array}{l}-2.7 \\
-2.9\end{array}$ & $\begin{array}{l}-1.2 \\
-1.4\end{array}$ \\
\hline C. $S$. & $\begin{array}{l}\text { Fluid } \\
\text { Serum }\end{array}$ & $\begin{array}{l}3.08 \\
7.06\end{array}$ & $\begin{array}{l}64.2 \\
57.1\end{array}$ & $\begin{array}{l}5.2 \\
5.8\end{array}$ & $\begin{array}{l}6.9 \\
9.5\end{array}$ & $\begin{array}{l}14.3 \\
15.7\end{array}$ & $\begin{array}{r}9.4 \\
11.9\end{array}$ & -9.0 & $\begin{array}{l}-6.4 \\
-6.2\end{array}$ & $\begin{array}{l}-5.2 \\
-5.0\end{array}$ & $\begin{array}{l}-4.4 \\
-4.0\end{array}$ & $\begin{array}{l}-2.7 \\
-2.6\end{array}$ & $\begin{array}{l}-1.4 \\
-1.1\end{array}$ \\
\hline
\end{tabular}

* Protein concentrations: 1.8 per cent; in sodium diethylbarbiturate buffer of pH 8.6 and 0.1 ionic strength.

the erythrocyte sedimentation rate and the classification of patterns into Groups $A$ and $B$, respectively.

A relationship between the electrophoretic distribution of protein fractions and the duration of effusion is suggested by the fact that five cases of

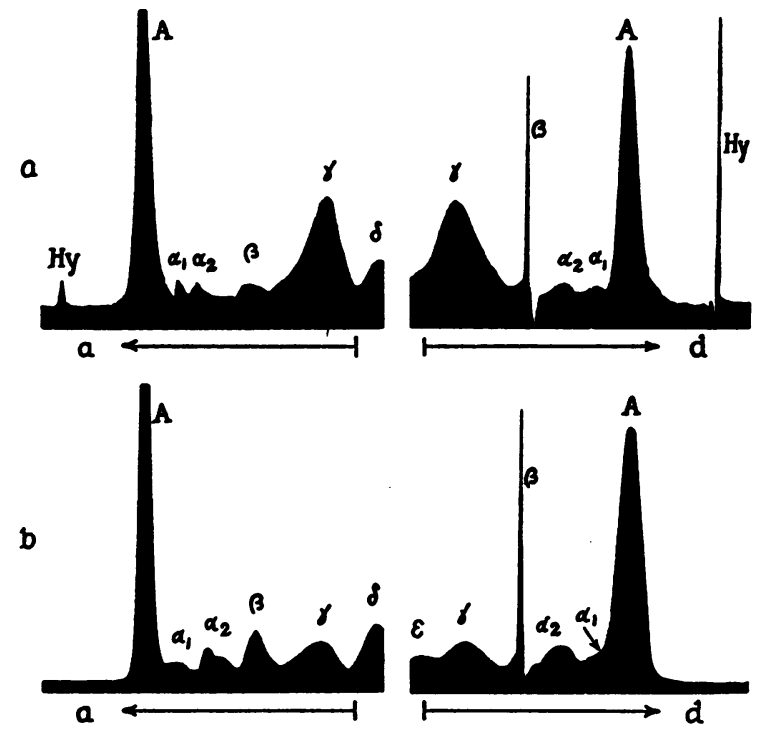

Figs. 3a ANd 3b. Electrophoretic Patterns of a 1.8 Per Cent Solution of Proteins of the Synovial Flum (a) and the Serum (b) of a Patient with Rheumatold Arthritis, Representative of Group C

Electrophoresis was carried out in sodium diethylbarbiturate buffer of $\mathrm{pH} 8.6$ and $\Gamma / 20.1$ for 14,400 seconds at a potential gradient of 5.2 volts per centimeter.
Group A had effusions for less than eight months, which was the case for only one patient of Group B. Moreover, if effusion persisted for a longer period, an increase in the average concentration of $\gamma$-globulin became apparent. Thus, the relative concentration of this protein in fluids of less than one year was 17.5 per cent, compared with 46 per cent in those of five to ten years' duration.

The three patients included in Group C presented varied clinical pictures, ranging from mild to severe, with sedimentation rates of 0.14 to 1.2 $\mathrm{mm}$. per minute and joint effusions lasting from 14 months to nine years. The only consistent finding in these three cases was that the arthritis in the knee from which the fluid was aspirated seemed of mild nature. Moreover, in two of the patients the changes in the other fluid findings (number of polymorphonuclear leukocytes, type of mucin precipitate and concentration of sugar) were also slight. The exceptionally low content of protein (3.2 per cent) in the one fluid of this type reported by Svartz and Olhagen (3) is of interest.

There is no apparent correlation in the three groups between the cell count, the character of the mucin, and the electrophoretic distribution of proteins. However, the average total protein concentration of the joint fluids of Group A, i.e., 4.4 per cent, is lower than the 5.4 per cent found in Group B.

In one fluid the electrophoretic pattern disclosed 
TABLE II

Electrophoretic distribution of proteins in serum and synovial fluid from patients with rheumatoid arthritis *

\begin{tabular}{|c|c|c|c|c|c|c|c|c|c|c|c|c|c|c|}
\hline \multirow{3}{*}{$\begin{array}{l}\text { Unit } \\
\text { No. }\end{array}$} & & \multirow{3}{*}{$\begin{array}{c}\text { Total } \\
\text { protein } \\
\text { Gm. } / 100 \text { cc. }\end{array}$} & \multicolumn{5}{|c|}{ Concentrations in per cent as } & \multicolumn{3}{|c|}{ Joint fluid } & \multirow{3}{*}{$\begin{array}{c}\text { Stage } \\
\text { of } \\
\text { diseaset }\end{array}$} & \multirow{3}{*}{$\begin{array}{l}\text { Func- } \\
\text { tional } \\
\text { classifi- } \\
\text { cation† }\end{array}$} & \multirow{3}{*}{$\begin{array}{c}\text { Duration } \\
\text { of } \\
\text { effusion }\end{array}$} & \multirow{3}{*}{$\begin{array}{c}\text { Sedimen- } \\
\text { tation } \\
\text { rate } \\
\text { mm. } / \text { min }\end{array}$} \\
\hline & & & \multirow{2}{*}{$\begin{array}{c}\text { Albu- } \\
\text { min }\end{array}$} & \multicolumn{4}{|c|}{ Globulins } & \multirow{2}{*}{$\begin{array}{c}\text { Leuko- } \\
\text { cytes } \\
\text { per cu. } \mathrm{mm} .\end{array}$} & \multirow{2}{*}{$\begin{array}{c}\text { Poly- } \\
\text { morpho- } \\
\text { nuclears } \\
\%\end{array}$} & \multirow{2}{*}{$\begin{array}{c}\text { Type } \\
\text { of } \\
\text { mucin } \\
\text { ppt. }\end{array}$} & & & & \\
\hline & & & & $\alpha_{1}$ & $\alpha_{2}$ & $\beta$ & $\boldsymbol{\gamma}$ & & & & & & & \\
\hline \multicolumn{15}{|c|}{ Group $A$} \\
\hline 311289 & $\begin{array}{l}\text { Fluid } \\
\text { Serum }\end{array}$ & $\begin{array}{l}3.98 \\
7.56\end{array}$ & $\begin{array}{l}51.5 \\
41.0\end{array}$ & $\begin{array}{l}6.6 \\
7.5\end{array}$ & $\begin{array}{r}8.6 \\
10.0\end{array}$ & $\begin{array}{l}11.6 \\
15.4\end{array}$ & $\begin{array}{l}21.7 \\
26.1\end{array}$ & 10,000 & 54 & - & 2 & 3 & 2 yrs. & 1.09 \\
\hline 594438 & $\begin{array}{l}\text { Fluid } \\
\text { Serum }\end{array}$ & $\begin{array}{l}4.91 \\
6.69\end{array}$ & $\begin{array}{l}37.8 \\
32.3\end{array}$ & $\begin{array}{l}10.7 \\
10.8\end{array}$ & $\begin{array}{l}13.4 \\
17.3\end{array}$ & $\begin{array}{l}18.7 \\
17.6\end{array}$ & $\begin{array}{l}19.4 \\
22.0\end{array}$ & 62,200 & 91 & poor & 2 & 4 & 2 mos. & 1.37 \\
\hline 330748 & $\begin{array}{l}\text { Fluid } \\
\text { Serum }\end{array}$ & $\begin{array}{l}4.41 \\
7.44\end{array}$ & $\begin{array}{l}47.2 \\
43.1\end{array}$ & $\begin{array}{l}6.3 \\
6.7\end{array}$ & $\begin{array}{r}8.2 \\
12.0\end{array}$ & $\begin{array}{l}11.2 \\
11.3\end{array}$ & $\begin{array}{l}27.1 \\
26.9\end{array}$ & 12,600 & 78 & fair & 3 & 3 & 4 yrs. & 1.36 \\
\hline 565573 & $\begin{array}{l}\text { Fluid } \\
\text { Serum }\end{array}$ & $\begin{array}{l}4.00 \\
6.06\end{array}$ & $\begin{array}{l}57.4 \\
53.1\end{array}$ & $\begin{array}{l}5.6 \\
5.5\end{array}$ & $\begin{array}{l}10.0 \\
12.6\end{array}$ & $\begin{array}{l}14.9 \\
15.7\end{array}$ & $\begin{array}{l}12.1 \\
13.1\end{array}$ & 450 & 68 & good & 1 & 2 & 2 wks. & 0.44 \\
\hline 507225 & $\begin{array}{l}\text { Fluid } \\
\text { Serum }\end{array}$ & $\begin{array}{l}5.19 \\
7.56\end{array}$ & $\begin{array}{l}53.6 \\
50.4\end{array}$ & $\begin{array}{l}5.0 \\
5.0\end{array}$ & $\begin{array}{l}15.5 \\
11.8\end{array}$ & $\begin{array}{l}14.6 \\
19.7\end{array}$ & $\begin{array}{l}11.3 \\
13.1\end{array}$ & 10,150 & 4 & fair & 1 & 2 & 2 wks. & 1.09 \\
\hline \multicolumn{15}{|c|}{ Group B } \\
\hline 147485 & $\begin{array}{l}\text { Fluid } \\
\text { Serum }\end{array}$ & $\begin{array}{l}5.45 \\
7.88\end{array}$ & $\begin{array}{l}51.3 \\
51.2\end{array}$ & $\begin{array}{l}5.4 \\
5.6\end{array}$ & $\begin{array}{r}9.4 \\
12.2\end{array}$ & $\begin{array}{r}9.8 \\
12.7\end{array}$ & $\begin{array}{l}24.1 \\
18.3\end{array}$ & 11,300 & 36 & fair & 2 & 2 & 3 yrs. & 0.72 \\
\hline 389209 & $\begin{array}{l}\text { Fluid } \\
\text { Serum }\end{array}$ & $\begin{array}{l}5.94 \\
7.87\end{array}$ & $\begin{array}{l}32.3 \\
32.5\end{array}$ & $\begin{array}{l}6.6 \\
7.4\end{array}$ & $\begin{array}{r}8.1 \\
12.2\end{array}$ & $\begin{array}{l}17.1 \\
13.5\end{array}$ & $\begin{array}{l}35.9 \\
34.4\end{array}$ & 25,900 & 94 & fair & 2 & 3 & 14 mos. & 1.52 \\
\hline 499948 & $\begin{array}{l}\text { Fluid } \\
\text { Serum }\end{array}$ & $\begin{array}{l}6.43 \\
8.14\end{array}$ & $\begin{array}{l}31.9 \\
32.7\end{array}$ & $\begin{array}{l}6.1 \\
7.6\end{array}$ & $\begin{array}{l}13.0 \\
18.9\end{array}$ & $\begin{array}{l}12.5 \\
12.2\end{array}$ & $\begin{array}{l}36.5 \\
28.6\end{array}$ & 13,850 & 88 & $\begin{array}{l}\text { very } \\
\text { poor }\end{array}$ & 2 & 3 & 3 yrs. & 1.22 \\
\hline 636487 & $\begin{array}{l}\text { Fluid } \\
\text { Serum }\end{array}$ & $\begin{array}{l}5.09 \\
6.81\end{array}$ & $\begin{array}{l}48.0 \\
47.0\end{array}$ & $\begin{array}{l}7.1 \\
6.4\end{array}$ & $\begin{array}{l}10.6 \\
12.3\end{array}$ & $\begin{array}{l}14.1 \\
16.1\end{array}$ & $\begin{array}{l}20.2 \\
18.2\end{array}$ & 14,200 & 74 & $\begin{array}{l}\text { very } \\
\text { poor }\end{array}$ & 3 & 2 & $1 \mathrm{yr}$. & 1.38 \\
\hline \multicolumn{15}{|c|}{ Group $C$} \\
\hline 350995 & $\begin{array}{l}\text { Fluid } \\
\text { Serum }\end{array}$ & $\begin{array}{l}5.63 \\
7.32\end{array}$ & $\begin{array}{l}42.2 \\
46.0\end{array}$ & $\begin{array}{l}4.1 \\
5.7\end{array}$ & $\begin{array}{r}7.5 \\
10.9\end{array}$ & $\begin{array}{l}11.0 \\
14.8\end{array}$ & $\begin{array}{l}35.2 \\
22.6\end{array}$ & 7,900 & 69 & $\begin{array}{l}\text { very } \\
\text { poor }\end{array}$ & 3 . & 4 & 9 yrs. & 1.06 \\
\hline 389847 & $\begin{array}{l}\text { Fluid } \\
\text { Serum }\end{array}$ & $\begin{array}{l}5.52 \\
7.25\end{array}$ & $\begin{array}{l}44.2 \\
59.8\end{array}$ & $\begin{array}{l}2.9 \\
3.7\end{array}$ & $\begin{array}{l}4.8 \\
9.0\end{array}$ & $\begin{array}{r}6.9 \\
12.6\end{array}$ & $\begin{array}{l}41.2 \\
14.9\end{array}$ & 10,350 & 4 & good & 1 & 1 & 14 mos. & 0.14 \\
\hline
\end{tabular}

* Protein concentrations: 1.8 per cent; in sodium diethylbarbiturate buffer of $\mathrm{pH} 8.6$ and 0.1 ionic strength.

† See Footnote 7 to text.

a peak migrating with a mobility intermediate to those of hyaluronic acid and albumin, similar to those described by Schürch, Viollier, and Süllmann (4). Similar findings have been reported in the literature by Chargaff, Ziff, and Moore (14) for the electrophoresis of mixtures of heparin and plasma and by Partridge (15) in his work on chondromucoid. These investigators assumed that this intermediate peak may represent a complex of polysaccharide and protein, but, as yet, there is not adequate evidence to support such an explanation for the finding made in this laboratory.

In two patients bilateral knee effusions were present, and fluid was aspirated for electrophoretic analysis. As shown in Table III, the distribution of protein components was the same in both knees. This is of interest in view of the finding that in many patients with bilateral effusions, the cytology, nature of mucin and total concentration of protein are quite similar in both fluids (6).

\section{DISCUSSION}

The results of the electrophoretic study of synovial fluids in rheumatoid arthritis show a wide range of distribution of the relative concentration of the individual protein fractions. The only relation between the electrophoretic pattern and the severity of the joint disease is that mild cases tend 
to show patterns similar to those found in traumatic arthritis. A better correlation was found between the distribution of the protein fractions and the duration of the effusion. The protein patterns of fluids of short duration resembled those of traumatic fluids, while in those of longer duration the distribution of the individual proteins in the fluid approached that of the serum. Moreover, the relative concentration of $\gamma$-globulin tended to rise with persistence of the effusion.

The relationship of the synovial fluid proteins to those of serum is unknown. The fact that migration patterns of joint fluid, as demonstrated with the aid of Figures 1, 2 and 3, show electrophoretically well-defined proteins with mobilities similar to those of albumin, $\alpha_{1^{-}}, \alpha_{2^{-}}, \beta-$ and $\gamma-$ globulin of serum, does not prove chemical identity. The low concentration of albumin and globulin found in normal synovial fluid has generally been ascribed to slight capillary permeability (see review [16]) and the increase in joint effusions is assumed to be due to an alteration in this permeability. The relatively high concentration of albumin in traumatic and in many mild rheumatoid fluids suggests that the normal differential permeability to various protein fractions persists when the inflammation is mild. On the other hand, the similarity of the relative concentration of the individual fractions in serum and fluid in many cases of active, moderately severe rheumatoid arthritis suggests complete permeability in these cases.

In addition to the factor of permeability in determining the concentration of protein and the ratio of one fraction to another in the joint fluid, diminished rate of removal by the lymphatics and possibly production of one or more protein fractions locally in the tissues, either by a synthetic mechanism or by tissue destruction, may play a role. There is, as yet, no proof of the latter mechanism, but suggestive evidence that it is possible is furnished by one case of rather mild rheumatoid arthritis in which the serum protein pattern was entirely normal but the fluid contained 41.2 per cent of $\gamma$-globulin (Figure 3 and Table II, Case 389847).

\section{SUM MARY}

The electrophoretic patterns of 31 synovial fluids from 21 patients with rheumatoid arthritis have been determined and compared with those of traumatic effusions (representing relatively normal fluids).

The fluids could be divided into three groups: A) With a relative albumin concentration higher in the fluid than the serum; B) with albumin concentrations equal; and $C$ ) with the albumin fraction lower in the fluid.

The distribution of proteins suggests only a possible correlation with the severity of the disease, but does show a definite relation to the duration of effusion.

Fluids obtained from bilateral knee effusions in two patients gave identical electrophoretic patterns.

ADDENDUM

\section{Electrophoretic Distribution of Proteins in Serum and Synovial Fluid in Other Rheumatic Diseases}

Few synovial fluids from other joint diseases have been studied electrophoretically. However,

TABLE III

Electrophoretic distribution of proteins in serum and synovial fluid from bilateral effusions in rheumatoid arthritis *

\begin{tabular}{|c|c|c|c|c|c|c|c|c|c|c|c|c|c|c|}
\hline \multirow{3}{*}{$\begin{array}{l}\text { Unit } \\
\text { No. }\end{array}$} & & \multirow{3}{*}{$\begin{array}{c}\text { Total } \\
\text { protein } \\
\mathrm{Gm} . / 100 \mathrm{cc} .\end{array}$} & \multicolumn{5}{|c|}{ Concentrations in per cent as } & \multicolumn{3}{|c|}{ Joint fluid } & \multirow{3}{*}{$\begin{array}{c}\text { Stage } \\
\text { of } \\
\text { diseaset }\end{array}$} & \multirow{3}{*}{$\begin{array}{l}\text { Func- } \\
\text { tional } \\
\text { classifi- } \\
\text { cation } \dagger\end{array}$} & \multirow{3}{*}{$\begin{array}{l}\text { Duration } \\
\text { of } \\
\text { effusion } \\
\text { yrs. }\end{array}$} & \multirow{3}{*}{$\begin{array}{c}\text { Sedimen- } \\
\text { tation- } \\
\text { rate } \\
\text { mm./min. }\end{array}$} \\
\hline & & & \multirow{2}{*}{$\underset{\text { min }}{\text { Albu- }}$} & \multicolumn{4}{|c|}{ Globulins } & \multirow{2}{*}{$\begin{array}{c}\text { Leuko- } \\
\text { cytes } \\
\text { per } c u . m m .\end{array}$} & \multirow{2}{*}{$\begin{array}{c}\text { Poly- } \\
\text { morpho- } \\
\text { nuclears } \\
\%\end{array}$} & \multirow{2}{*}{$\begin{array}{c}\text { Type } \\
\text { of } \\
\text { mucin } \\
\text { ppt. }\end{array}$} & & & & \\
\hline & & & & $\alpha_{1}$ & $\alpha$ & $\boldsymbol{\beta}$ & $\gamma$ & & & & & & & \\
\hline 210563 & $\begin{array}{l}\text { Fluid-L } \\
\text { Fluid-R } \\
\text { Serum }\end{array}$ & $\begin{array}{l}5.26 \\
5.38 \\
7.06\end{array}$ & $\begin{array}{l}47.7 \\
46.7 \\
48.5\end{array}$ & $\begin{array}{l}3.2 \\
4.2 \\
4.7\end{array}$ & $\begin{array}{l}5.5 \\
5.4 \\
8.5\end{array}$ & $\begin{array}{r}7.7 \\
7.6 \\
13.3\end{array}$ & $\begin{array}{l}35.9 \\
36.1 \\
25.0\end{array}$ & $\begin{array}{l}4,750 \\
5,500\end{array}$ & $\begin{array}{l}8 \\
8\end{array}$ & $\begin{array}{l}\text { good } \\
\text { good }\end{array}$ & 1 & 1 & $\begin{array}{l}5 \frac{1}{2} \\
5 \frac{1}{2}\end{array}$ & 0.78 \\
\hline 270773 & $\begin{array}{l}\text { Fluid-L } \\
\text { Fluid-R } \\
\text { Serum }\end{array}$ & $\begin{array}{l}7.37 \\
7.37 \\
7.93\end{array}$ & $\begin{array}{l}20.4 \\
20.9 \\
33.7\end{array}$ & $\begin{array}{l}3.4 \\
3.6 \\
6.8\end{array}$ & $\begin{array}{r}4.4 \\
4.6 \\
13.8\end{array}$ & $\begin{array}{r}5.0 \\
4.9 \\
13.4\end{array}$ & $\begin{array}{l}66.8 \\
66.0 \\
32.3\end{array}$ & $\begin{array}{l}3,500 \\
2,800\end{array}$ & $\begin{array}{r}7 \\
17\end{array}$ & $\begin{array}{l}\text { good } \\
\text { good }\end{array}$ & 2 & 2 & $\begin{array}{l}8 \\
8\end{array}$ & 0.78 \\
\hline
\end{tabular}

* Protein concentrations: 1.8 per cent; in sodium diethylbarbiturate buffer of $\mathrm{pH} 8.6$ and 0.1 ionic strength. † See Footnote 7 to text. 
TABLE IV

Electrophoretic distribution of proteins in serum and synovial fluid from various rheumatic diseases *

\begin{tabular}{|c|c|c|c|c|c|c|c|c|c|c|c|}
\hline \multirow{3}{*}{$\begin{array}{l}\text { Unit } \\
\text { No. }\end{array}$} & & \multirow{3}{*}{$\begin{array}{c}\text { Total } \\
\text { protein } \\
\mathrm{Gm} . / 100 \mathrm{cc} .\end{array}$} & \multicolumn{5}{|c|}{ Concentrations in per cent as } & \multicolumn{3}{|c|}{ Joint fluid } & \multirow{3}{*}{$\begin{array}{c}\text { Sedimen } \\
\text { tation } \\
\text { rate } \\
\text { mm. } / \text { mix }\end{array}$} \\
\hline & & & \multirow[b]{2}{*}{ Albumin } & \multicolumn{4}{|c|}{ Globulins } & \multirow{2}{*}{$\begin{array}{c}\text { Leuko- } \\
\text { cytes } \\
\text { per cu. mm. }\end{array}$} & \multirow{2}{*}{$\begin{array}{c}\text { Polymorpho- } \\
\text { nuclears } \\
\% \\
\end{array}$} & \multirow{2}{*}{$\begin{array}{c}\text { Type of } \\
\text { mucin } \\
\text { ppt. }\end{array}$} & \\
\hline & & & & $\alpha_{1}$ & $\alpha_{2}$ & $\boldsymbol{\beta}$ & $\boldsymbol{r}$ & & & & \\
\hline \multicolumn{12}{|c|}{ Rheumatic Fever } \\
\hline 334510 & $\begin{array}{l}\text { Fluid } \\
\text { Serum }\end{array}$ & $\begin{array}{l}5.15 \\
7.91\end{array}$ & $\begin{array}{l}36.7 \\
32.5\end{array}$ & $\begin{array}{r}6.9 \\
11.5\end{array}$ & $\begin{array}{r}8.8 \\
16.2\end{array}$ & $\begin{array}{l}15.0 \\
14.1\end{array}$ & $\begin{array}{l}32.6 \\
25.7\end{array}$ & 18,650 & 84 & fair & 1.71 \\
\hline 291855 & $\begin{array}{l}\text { Fluid } \\
\text { Serum }\end{array}$ & $\begin{array}{l}4.58 \\
7.56\end{array}$ & $\begin{array}{l}43.3 \\
36.4\end{array}$ & $\begin{array}{l}9.1 \\
9.3\end{array}$ & $\begin{array}{l}12.9 \\
17.7\end{array}$ & $\begin{array}{l}15.9 \\
14.9\end{array}$ & $\begin{array}{l}18.8 \\
21.7\end{array}$ & 8,500 & 73 & fair & - \\
\hline \multicolumn{12}{|c|}{ Gout } \\
\hline 704258 & $\begin{array}{l}\text { Fluid } \\
\text { Serum }\end{array}$ & $\begin{array}{l}4.42 \\
6.38\end{array}$ & $\begin{array}{l}44.5 \\
39.4\end{array}$ & $\begin{array}{l}8.4 \\
8.6\end{array}$ & $\begin{array}{l}11.3 \\
12.6\end{array}$ & $\begin{array}{l}17.3 \\
16.6\end{array}$ & $\begin{array}{l}18.5 \\
22.8\end{array}$ & 11,100 & 92 & fair & - \\
\hline \multicolumn{12}{|c|}{ Reiter's Syndrome } \\
\hline 694675 & $\begin{array}{l}\text { Fluid } \\
\text { Serum }\end{array}$ & $\begin{array}{l}4.29 \\
6.50\end{array}$ & $\begin{array}{l}51.8 \\
48.8\end{array}$ & $\begin{array}{r}8.1 \\
10.0\end{array}$ & $\begin{array}{l}12.9 \\
14.4\end{array}$ & $\begin{array}{l}15.7 \\
13.2\end{array}$ & $\begin{array}{l}11.5 \\
13.6\end{array}$ & 44,300 & 89 & poor & 0.97 \\
\hline 705909 & $\begin{array}{l}\text { Fluid } \\
\text { Serum }\end{array}$ & $\begin{array}{l}5.36 \\
7.25\end{array}$ & $\begin{array}{l}51.1 \\
49.4\end{array}$ & $\begin{array}{l}6.5 \\
6.7\end{array}$ & $\begin{array}{l}12.6 \\
14.6\end{array}$ & $\begin{array}{l}16.6 \\
14.0\end{array}$ & $\begin{array}{l}13.2 \\
15.3\end{array}$ & 2,566 & 22 & $\begin{array}{l}\text { very } \\
\text { poor }\end{array}$ & 1.70 \\
\hline \multicolumn{12}{|c|}{ Intermittent Hydrarthrosis } \\
\hline 563722 & $\begin{array}{l}\text { Fluid } \\
\text { Serum }\end{array}$ & $\begin{array}{l}4.89 \\
6.94\end{array}$ & $\begin{array}{l}51.6 \\
47.7\end{array}$ & $\begin{array}{l}6.8 \\
6.2\end{array}$ & $\begin{array}{r}9.4 \\
12.7\end{array}$ & $\begin{array}{l}17.8 \\
18.2\end{array}$ & $\begin{array}{l}14.4 \\
15.2\end{array}$ & 41,200 & 86 & $\begin{array}{l}\text { very } \\
\text { poor }\end{array}$ & 0.46 \\
\hline \multicolumn{12}{|c|}{ Hypertrophic Pulmonary Osteoarthropathy } \\
\hline 694222 & $\begin{array}{l}\text { Fluid } \\
\text { Serum }\end{array}$ & $\begin{array}{l}3.27 \\
5.87\end{array}$ & $\begin{array}{l}45.1 \\
33.6\end{array}$ & $\begin{array}{l}13.6 \\
12.4\end{array}$ & $\begin{array}{l}12.5 \\
21.2\end{array}$ & $\begin{array}{l}13.1 \\
15.3\end{array}$ & $\begin{array}{l}15.7 \\
17.5\end{array}$ & 3,000 & 44 & fair & 1.57 \\
\hline
\end{tabular}

* Protein concentrations: 1.8 per cent; in sodium diethylbarbiturate buffer of $\mathrm{pH} 8.6$ and 0.1 ionic strength.

comparison of the results available with those from rheumatoid and traumatic fluids is of interest.

The electrophoretic distribution of proteins in two synovial fluids from patients with rheumatic fever resembled that found in Group A of the rheumatoid fluids with the albumin concentration higher in the fluid than in the serum (Table IV). Two of the cases reported by Svartz and Olhagen (3) showed similar patterns, whereas in the third the concentrations in the fluid were essentially the same as in the serum.

In one patient with gout, two patients with Reiter's syndrome, one with intermittent hydrarthrosis, and one with hypertrophic pulmonary osteoarthropathy, the electrophoretic distribution of proteins in the synovial fluid resembled that in Group $\mathrm{A}$ of the rheumatoid fluids, the albumin content being higher in the fluid than in the serum (Table IV).

In all cases, as in the rheumatoid fluids, the $\alpha_{1}$ and $\beta$-globulin concentrations were essentially the same in fluid and serum, and the $\alpha_{2}$-globulin fraction was lower in the fluid.

\section{REFERENCES}

1. Ropes, M. W., Perlmann, G. E., Kaufman, D., and Bauer, W., The electrophoretic distribution of proteins in plasma in rheumatoid arthritis. J. Clin. Invest., 1954, 33, 311.

2. Perlmann, G. E., and Kaufman, D., Electrophoretic distribution of proteins in serum, plasma and synovial fluid of patients with rheumatoid arthritis. J. Clin. Invest., 1946, 25, 931.

3. Svartz, N., and Olhagen, B., Electrophoretic analysis of proteins in articular rheumatism. Acta med. Scandinav., 1948, 130, suppl. 206, 456. 
4. Schürch, O., Viollier, G., and Süllmann, H., Elektrophoretische Untersuchung von Kniegelenkergüssen. Schweiz. med. Wchnschr., 1950, 80, 711.

5. Olhagen, B., The protein pattern of joint exudates. Acta orthop. Scandinav., 1950, 21, 114.

6. Ropes, M. W., and Bauer, W., Synovial Fluid Changes in Joint Disease, Cambridge, Mass., Harvard University Press, 1953.

7. Perlmann, G. E. Unpublished data.

8. Hesselvik, L., An electrophoretic investigation on synovial fluid. Acta med. Scandinav., 1940, 105, 153.

9. Blix, G., Studies in glycoproteins. Acta physiol. Scandinav., 1940, 1, 29.

10. Perlmann, G. E., Glenn, W. W. L., and Kaufman, D., Changes in the electrophoretic pattern in lymph and serum in experimental burns. J. Clin. Invest., 1943, 22, 627.

11. Meyer, K., and Chaffee, E., Hyaluronic acid in the pleural fluid associated with a malignant tumor in- volving the pleura and peritoneum. J. Biol. Chem., 1940, 133, 83.

12. Perlmann, G. E., Tamm, I., and Horsfall, F. L., Jr., An electrophoretic examination of a urinary mucoprotein which reacts with various viruses. J. Exper. Med., 1952, 95, 99.

13. Steinbrocker, O., Traeger, C. H., and Batterman, R. C., Therapeutic criteria in rheumatoid arthritis. J. A. M. A., 1949, 140, 659.

14. Chargaff, E., Ziff, M., and Moore, D. H., Studies on the chemistry of blood coagulation. XII. An electrophoretic study of the effect of anticoagulants on human plasma proteins, with remarks on the separation of the heparin complement. J. Biol. Chem., 1941, 139, 383.

15. Partridge, S. M., The chemistry of connective tissues. I. The state of combination of chondroitin sulphate in cartilage. Biochem. J., 1948, 43, 387.

16. Bauer, W., Ropes, M. W., and Waine, H., The physiology of articular structures. Physiol. Rev., 1940, 20, 272.

\section{SPECIAL NOTICE TO SUBSCRIBERS}

Post Offices will no longer forward the Journal when you move.

Please notify The Journal of Clinical Investigation, Business Office, 622 West 168th Street, New York 32, N. Y. at once when you have a change of address, and do not omit the zone number if there is one. 